\title{
EL RETRATO DE ESOPO EN LOS ISOPETES INCUNABLES: IMAGEN Y TEXTO
}

\author{
CARlos Alvar \\ CONSTANCE CARTA \\ SARAH FINCI \\ Université de Genève
}

El año 1482 se publicó el libro del Ysopete historiado, «el cual fue sacado de latín en romance e emplentado ('impreso') en la muy noble e leal ciudad de Çaragoça» ${ }^{1}$. En 1488 veía la luz en Toulouse una nueva edición, cuyo colofón - como en el caso anterior - nos hace saber que fue traducido del latín a la lengua romance, y añade que fue impreso por los «muy discretos maestros Joan Párix y Estevan Clebat». Un año más tarde, 1489, aparecía una nueva edición del libro, «el cual fue sacado de latín en romance et emplentado en la muy noble e leal cibdad de Çaragoça, por Johan Hurus alamán de Constancia». Y antes de que acabara el siglo, en 1496, Fadrique de Basilea imprimió en Burgos otra edición. En los cuatro casos, el libro va acompañado de abundantes xilografías que aluden a diversas fábulas del conocido autor griego.

Podemos considerar que los incunables en español constituyen los eslabones finales de una cadena que había empezado varios años antes en Alemania. En efecto, en 1461, Albrecht Pfister publicó en Bamberg Der Edelstein, posiblemente el primer libro ilustrado, en el que recogía cien fábulas de tradición esópica, aunque herederas del Romulus, y las acompañaba con ciento tres grabados $^{2}$. En 1476 o 1477 Johan Zainer imprimió en Ulm una edición bilingüe

\footnotetext{
${ }^{1}$ Descrito y estudiado con detalle por C. Navarro, «El incunable de 1482 y las ediciones del Isopete en España», Quaderni di Lingue e Letterature (Verona), 15, 1990, págs. 157-164 y por M. ${ }^{a}$ J. Lacarra, «La fortuna del Ysopete en España», en D. Smithbauer y D. Martín, eds., Actas del XIII Congreso Internacional de la Asociación Hispánica de Literatura Medieval, Valladolid, Universidad, 2011, págs. 105-133.

${ }^{2}$ C. Navarro, «Notas a la iconografía del Isopete español», Quaderni di Lingue e Letterature, 18, 1993, págs. 543-576.
} 
(alemán-latín) de las Fábulas de Esopo llevada a cabo por Heinrich Steinhöwel, que tomó como base para su trabajo alguna de las colecciones medievales conocidas con el nombre de Romulus, que no eran sino la versión latina de una serie de fábulas (unas 150, muchas perdidas después) atribuidas a Esopo y traducidas en verso por Fedro (h. 18 a. C.-54 d. C.). La obra de Steinhöwel tuvo gran éxito y en época posterior se le fueron añadiendo otros relatos, pero el éxito no se debió sólo al texto, sino también a las numerosas ilustraciones que lo acompañaban y que se repitieron, copiaron o imitaron cada vez que se publicó una nueva versión del libro. Y así ocurrió en 1480, cuando Nicolas, Philippe y Marc Reinhard, impresores alemanes asentados en Lyon, publicaron las fábulas de Esopo traducidas por Julien Macho, utilizando las xilografías de la edición de Zainer pocos años anterior. Luego, la versión española reutilizaría los mismos grabados.

\section{LA TRADICIÓN MEDIEVAL DE LAS FÁBULAS DE ESOPO}

La recepción medieval de la obra de Esopo fue trazada hace más de un siglo por L. Hervieux en su extenso estudio acerca de los fabulistas latinos, desde la época de Augusto hasta finales de la Edad Media (1893-1899) ${ }^{3}$. Basta con seguir el planteamiento de esta obra — mezcla de novela policíaca y de profunda erudición filológica - para comprender la importancia de autores como Fedro, heredero en gran medida de la tradición griega emanada de la versión que Demetrio de Falero llevó a cabo de las Fábulas de Esopo; y aunque la colección de Demetrio aún pervivía en el siglo IX, no tardó en perderse igual que toda la obra de su predecesor. Así, Fedro se convierte en el principal pilar de la tradición esópica, que encontrará en Babrio un complemento imprescindible para nuestros conocimientos actuales. En todo caso, ni el uno, ni el otro transmitieron todas las fábulas de Esopo, y de ahí la necesidad de reunir los diferentes códices, pues entre las repeticiones no es raro que aparezcan grupos de fábulas perdidos en alguna de las ramas textuales.

En la Edad Media, se puede seguir el rastro de la obra de Fedro gracias a los escasos manuscritos existentes (apenas cinco, uno de los cuales se ha perdido) y, sobre todo, gracias a los numerosos imitadores directos o casi directos que tuvo. En este sentido, la desaparición del Aesopus ad Rufum hace recaer todo el peso de la tradición sobre la colección de fábulas atribuidas a Rómulo Augústulo: en la dedicatoria de varios manuscritos aparece el título de emperador junto al nombre de Romulus y en algunos casos llega a afirmarse que el autor lo tradujo del griego al latín. Pero la atribución carece de mayor funda-

${ }^{3}$ L. Hervieux, Les fabulistes latins. Depuis le siècle d'Auguste jusqu'à la fin du moyen âge, $2^{\text {ème }}$ éd., Paris, 1893-1899 [reimp. Hildesheim-New York, Georg Olms Verlag, 1970, 5 vols.]. 
mento, lo que no impediría que la colección alcanzara gran éxito durante la Edad Media: se trata de una serie de 84 fábulas en prosa ${ }^{4}$ en las que se incluyen tanto las de Fedro, como otras 32 procedentes de otro origen. Como hemos dicho, el Romulus se convierte, así, en heredero de Fedro y, como tal, en base indirecta y tardía de la difusión de la obra de Esopo durante la Edad Media: de él derivarán las colecciones de Walter de Inglaterra (Gualterius Anglicus) y de Ademar de Chabannes, conocidas durante el siglo XIX y aun después, como Romulus Neveletii y Romulus Nilantii respectivamente, en referencia a sus editores primeros ${ }^{5}$.

Pero durante la Edad Media también se conocieron las fábulas de Aviano, que en parte pasaron a enriquecer la tradición de Romulus, como atestiguan algunos manuscritos franceses de la familia del Isopet I de Paris, que junto a 58 fábulas procedentes de la compilación de Gualterius Anglicus, acoge 18 traducidas de Aviano.

Cuando Steinhöwel se dispuso a realizar su edición de las fábulas de Esopo, actuó como correspondía a un humanista: compiló los materiales existentes a su alcance y los ordenó para publicar en latín y en alemán los textos que le llegaban a través del Romulus, enriqueciéndolos con las fábulas «extravagantes», de tradición antigua, pero ajenas a la transmisión de la obra de Fedro; incorporó las traducidas del griego al latín por Rinuccio d'Arezzo ${ }^{6}$ a mediados del siglo XV y las de Aviano; añadió otras recogidas en Disciplina clericalis de Pedro Alfonso y en las Faceciae de Poggio Bracciolini y, finalmente, incorporó un grupo de origen diverso. Para completar su libro, Steinhöwel colocó al frente la traducción de la Vida de Esopo del bizantino Maximus Planudes, realizada por Rinuccio d'Arezzo, y cerró el conjunto con unos índices que facilitaban la utilización con fines didácticos de las fábulas reunidas.

A grandes rasgos, se puede establecer un stemma simplificado de la rica tradición textual que une al fabulista griego del siglo VI a. C. con los incunables de Zaragoza, Toulouse y Burgos. Es evidente que cada una de las ramas

${ }^{4}$ L. Hervieux, Les fabulistes latins, op. cit., I, pág. 306.

${ }^{5}$ Isaac Nicholas Nevelet, Mythologia Aesopica, Francfurt, Nicolas Hoffman, 1610, aunque hubo numerosas ediciones anteriores. Nevelet reunió casi 300 fábulas, entre las que se encuentran las de Walter (cfr. L. Hervieux, Les fabulistes latins, op. cit., I, págs. 631-632); Jean-Frédéric Nilant, Fabulae antiquae ex Phaedro, etc. Leyden, Thédore Haak, 1709 (cfr. L. Hervieux, Les fabulistes latins, op. cit., I, págs. 261 y 266). En realidad, el Romulus Neveletii es un repertorio de materiales procedentes de distintos códices ( 5 manuscritos para un total de 136 fábulas), según afirma el autor; la base es el manuscrito de la Biblioteca Palatina en el Vaticano (con la signatura 1710 en tiempos de Hervieux), de finales del siglo XIII (cfr. L. Hervieux, Les fabulistes latins, op. cit., I, págs. 586-588).

${ }^{6}$ Rinuccio d'Arezzo, conocido también como Ranuccio d'Arezzo o da Castiglione, vivió entre 1380 y 1459 y es el Remigio autor de la traducción de una parte de las fábulas recogidas en el Esopete ystoriado, procedentes, como es obvio, de la versión alemana de Steinhöwel. 
puede enriquecerse con más testimonios, pero aquí nos encontramos con las líneas maestras que pueden contribuir a la comprensión de lo dicho hasta ahora, a la vez que facilitará el camino para transitar por el complejo panorama que nos queda. Hay que insistir, sin embargo, en el hecho de que las colecciones de fábulas reúnen textos que son en sí mismos unidades independientes, por lo que resultan fáciles las contaminaciones o la incorporación de materiales ajenos, como deja en evidencia la edición misma de las fábulas de Esopo realizada por Steinhöwel.

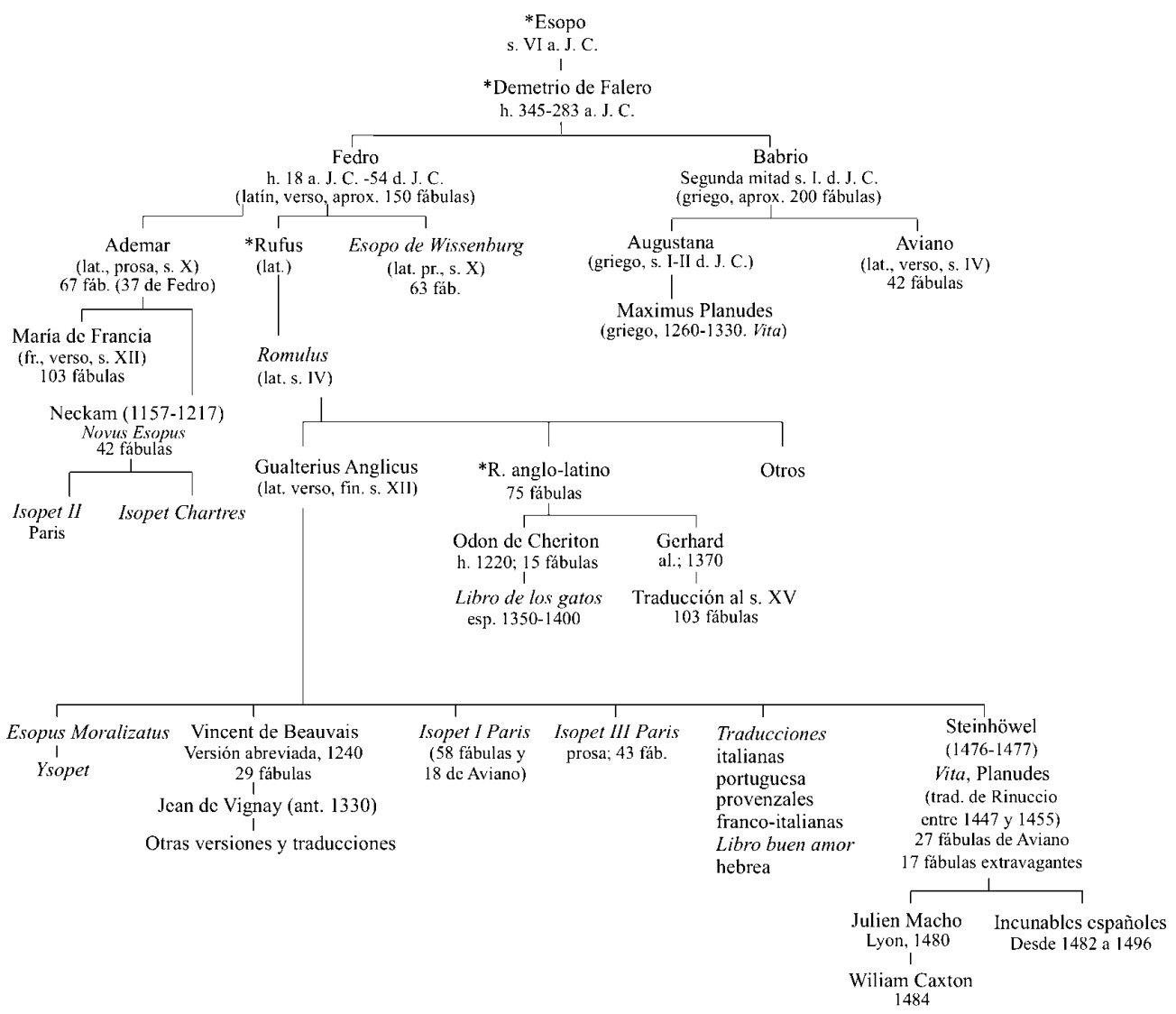

Esta proliferación de versiones diferentes, de textos y de testimonios sólo es explicable por la popularidad de las fábulas de Esopo (y de Fedro), debido a su presencia en las escuelas como apoyo para la enseñanza de gramática y retórica en los primeros años de aprendizaje: era frecuente encontrar en el nivel más bajo los escritos procedentes de los Dicta Catonis, la Ilias latina, Donato, 
Maximiano, Aviano y el Esopo latino ${ }^{7}$; posiblemente el destino de Esopo entre los minores, entre los rudimentis parvulorum apti hizo que su obra fuera conocida en diminutivo, Isopete, como Catúnculo, Homérulo o Avianonet ${ }^{8}$.

\section{A PROPÓSITO DE LA VIDA DE ESOPO}

La tradición textual deja claro que la obra de Esopo sólo fue conocida en la Edad Media de forma indirecta, a través de Fedro y de los imitadores de éste, o a través de Aviano. No sorprenderá, pues, que tampoco se sepa mucho del autor; o por ser más exactos, que no se sepa nada seguro del mismo9. Sin embargo, desde el siglo XIII circulaba una Vida del fabulista obra del monje bizantino Maximus Planudes (Maximos Planoudes, h. 1260-h. 1330), importante enlace cultural entre el mundo griego y latino de la Edad Media.

Planudes recurrió a un texto alejandrino del siglo I d.C. y a alguna biografía de Esopo similar a la que se recogía en la colección de fábulas conocida bajo el nombre de Augustana. Sobre esa base y con materiales hoy perdidos, pero que se pueden asociar a una tendencia ideológica bien definida, el monje bizantino construyó una Vida llena de elementos folclóricos y de alardes de ingenio que debieron divertir a algunos humanistas como Poggio, pues entraban de lleno en el dominio de las facecias y del humor rápido, a veces burdo y grosero.

Dos personajes constituyen el centro de esta Vida: un esclavo extranjero, contrahecho, pero muy ingenioso (Esopo) y su señor, filósofo griego, representante de los logros intelectuales helenos (Xantos); la confrontación de ambos

${ }^{7}$ B. Munk Olsen, I classici nel canone scolastico altomedievale. Spoleto, 1991, págs. 3 y sigs.; íd., L'étude des auteurs classiques latins aux XIe et XIIe siècles. Paris, 1982-1989. Para otros datos, véanse E. R. Curtius, Literatura europea y Edad Media latina. México-Madrid, FCE, 1955, págs. 80 y sigs., y P. Riché, Écoles et enseignement dans le haut Moyen Age, Paris, Aubier, 1979, pág. 228. Aimerico de Gâtinaux en su Arte lectoria, h. 1086, distribuye a los auctores en tres niveles: «In tercio, hoc est communi genere, alteros pones: Catunculum, Homerunculum, Maximianum, Avianum, Esopem» (cfr. T. González Rolán, P. Saquero y A. López Fonseca, La tradición clásica en España (siglos XIII-XV). Bases conceptuales y bibliográficas, Madrid, Ediciones clásicas, 2002, pág. 33).

${ }^{8}$ Los textos han sido publicados, en parte, por L. Hervieux; por lo que respecta a los franceses, véase J. Bastin, Recueil général des Isopets. 2 vols., Paris, SATF, 1929-1930. El texto castellano de 1488 ha sido publicado por V. A. Burrus y H. Goldberg, Esopete ystoriado (Toulouse 1488), Madison, HSMS, 1990 y hay una edición facsímil del de 1489 con estudio preliminar de E. Cotarelo, Fábulas de Esopo. Madrid, Real Academia Española, 1929. También hay facsímil del libro de Heinrich Steinhöwel, Aesops Leben und Fabeln sowie Fabeln und Schwänke anderer Herkunft, con estudio preliminar de P. Amelung, Ludwigsburg, Graz, Art- Buchbinderei, 1995.

${ }^{9}$ Las alusiones de Heródoto (Historia, 2, 134), Aristófanes (Las avispas, v. 1.446) y Plutarco (Moralia, 556) no permiten construir una biografía, pues apenas constituyen unas pocas referencias de escasa consistencia real; cfr., por ejemplo, Der kleine Pauly, Lexikon der Antike, 5 vols., München, DTV, 1979, vol. I, pág. 199. 
marca la superioridad del esclavo feo, muy en consonancia con las corrientes de la «comedia nueva griega» (siglo IV a. C.), más realista y más cercana a la vida cotidiana que el clásico Aristófanes. Autores como Menandro no buscaban la moralización, sino la diversión, que brotaba sin dificultad en el choque de amos y criados, de alcahuetas y soldados fanfarrones ${ }^{10}$. El modelo será seguido por Plauto y Terencio, y por la comedia latina medieval. La Comedia nueva se da en la misma época en la que Demetrio de Falero reunía las fábulas de Esopo, por lo que no tendría nada de particular el hecho de que el propio Demetrio o su entorno (era gran amigo de Menandro) fueran los autores de esa biografía disparatada, muy del gusto del momento.

La reelaboración de la Vida de Esopo en el ámbito cristiano alejandrino del siglo I cargó de valores morales la figura del fabulista contrahecho y su muerte se convirtió en un castigo divino, por sus pecados de presunción y orgullo, y no por haber ofendido a Apolo en su propio santuario de Delfos ${ }^{11}$.

Esopo se había convertido en un personaje folclórico ya desde época remota y bajo su nombre se daba cabida a todo tipo de relatos, de los más diversos orígenes, que con frecuencia se encuentran atribuidos a otros personajes no menos folclóricos o «folclorizados». Y es lógico pensar que, al menos en parte, las andanzas y las ingeniosas respuestas del protagonista eran percibidas como muestras de humor y de actitud provocadora, carnavalesca en ocasiones y antiejemplar casi siempre ${ }^{12}$.

El humanista italiano Rinuccio d'Arezzo, vinculado a la curia del papa Nicolás V e introductor en Occidente de la obra de Arquímedes, tradujo del griego al latín la Vida redactada por Planudes; terminó su tarea entre 1447 y 1455, fecha ésta en la que empezó a difundirse su versión de las fábulas de Esopo, a las que la biografía servía de accessus.

\footnotetext{
${ }^{10}$ H.-J. Newiger, «Die griechische Komödie» en Griechische Literatur, E. Vogt, ed. Wiesbaden, Athenaion, 1984, págs. 187-230; B. Zimmermann, Die griechische Komödie, Düsseldorf / Zürich, 1998; R. L. Hunter, The New Comedy of Greece and Rome. Cambridge U. P., 1985; J. García López «La comedia nueva: Menandro», en J. A. López Férez, dir., Historia de la literatura griega, Madrid, Cátedra, 1988, págs. 478-502.

11 B. E. Perry, Studies in the Text History of the Life and Fables of Aesop, Haverford (Pennsylvania), American Philological Association, 1936. Ll. W. Daly, Aesop wthout Morals, New York, Yoseloff, 1961. Véase, además, H. Goldberg, «The Vida de Ysopo. A Case of Comic Didactism», Anuario Medieval, I, 1989, págs. 114-125.

${ }^{12}$ F. Rodríguez Adrados, «La vida de Esopo y la Vida de Lazarillo de Tormes», RFE, 58, 1976, págs. 35-45.
} 


\section{LOS INCUNABLES EN CASTELLANO}

Como hemos indicado al comienzo, existen cuatro incunables de las Fábulas de Esopo en castellano ${ }^{13}$ :

1. Zaragoza, Pablo Hurus y Juan Planck, 1482. Ejemplar único que se conserva en la Biblioteca del Seminario Metropolitano de Pamplona. Cuenta con 125 xilografías, coloreadas a mano con verdes, rojos, amarillos y ocres. Carece de portada y de la página con el retrato de Esopo.

2. Tolosa, Johann Parix y Stephan Clebat, 1488. Ejemplar único en la John Rylands Library de la University of Manchester. Tiene 140 folios y 199 grabados. Publicado por V. A. Burrus y H. Goldberg. Madison, Hispanic Seminary of Medieval Studies, 1990.

3. Zaragoza, Juan Hurus, 1489. Ejemplar único en la Biblioteca del Monasterio de El Escorial, Inc. 32-I-13. 120 folios, con 194 grabados. Edición facsímil: Madrid, Real Academia Española, 1929, con introducción de E. Cotarelo y Mori. Es posible que éste fuera el ejemplar que se hallaba en la biblioteca de Isabel la Católica y que fue enviado de la Capilla Real de Granada al monasterio de El Escorial.

4. Burgos, Fadrique Alemán de Basilea, 22 de agosto de 1496. Ejemplar único en la Bibliohèque Nationale de France, en Paris, Res-2B-108. 102 folios y 200 xilografías.

Las divergencias principales entre las cuatro ediciones se producen al final del texto, en el apartado de las fábulas «colectas». Los dos incunables de Zaragoza son casi idénticos, con escasas variantes ortográficas. Se puede concluir, en definitiva, que los cuatro ejemplares derivan de un mismo original, que no es otro que la edición bilingüe alemán-latín, que hizo Heinrich Steinhöwel (1411-1479) de las fábulas de Esopo, publicada en Ulm en 1476 o 1477 y que iba acompañada de la Vida escrita por Planudes y traducida al latín por Rinuccio d'Arezzo; el libro presentaba, además, 205 xilografías, obras tal vez de Jörg Syrlin el Viejo, escultor de la sillería del coro de la catedral de Ulm en $1474^{14}$.

\footnotetext{
${ }^{13}$ Cfr. C. Navarro, «El incunable de 1482», art. cit.; M. ${ }^{a}$ J. Lacarra, «La fortuna del Ysopete en España», art. cit.

14 Véase, por ejemplo, L. Fischel, Bilderfolgen im frühen Buchdruck. Studien zur InkunabelIllustration in Ulm und Strassburg, Konstanz-Stuttgart, Jan Thorbecke Verlag, 1963.
} 


\section{EL RETRATO DE ESOPO}

Tanto la edición de Steinhöwel como los incunables españoles se inician con un retrato de Esopo que ocupa completa la página; el personaje está rodeado por una serie de motivos que aluden a distintos episodios de la Vida, de tal forma que «el retrato se convierte así en una síntesis iconográfica de la biografía novelada, pero también en una especie de «paratexto» que sirve de anuncio

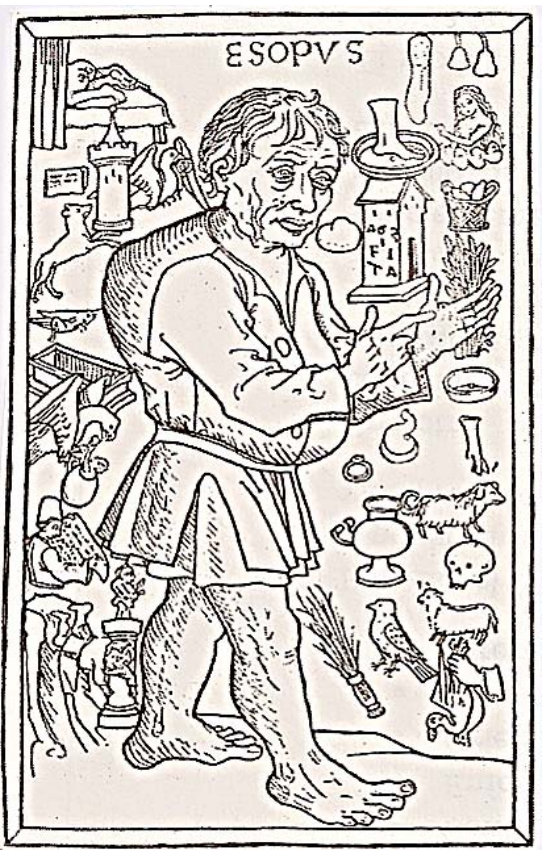

Fig. 1: Heinrich Steinhöwel. Ulm, 1476 o 1477.

y resumen del contenido, ante la falta de índice y de título» ${ }^{15}$.

Señala L. Fischel que en los incunables alemanes no es habitual la presencia del retrato del autor de este tamaño y con estas características. En el manuscrito más antiguo conservado de la tradición textual esópica, en la rama griega, del siglo $\mathrm{X} \mathrm{u}$ XI, se presenta al fabulista sentado, pero en un códice conservado en Moscú, de la misma rama, y del siglo XIV, se encuentra la representación del autor más en actitud de hablar que de escribir, y de ahí que sea retratado de pie, como en el incunable de Ulm, aunque con vestido largo y turbante; el gesto se repite en otros manuscritos vinculados a la tradición griega de Aviano y a la de Der Edelstein del bernés Ulrich Boner, que hallaría su expresión impresa en el trabajo de Albrecht Pfister (Bamberg, 1461; fig. 6) ${ }^{16}$.

Como vemos, no faltaron retratos de Esopo a lo largo de la Edad Media, en los que se suele representar al fabulista como un clérigo, hombre de letras, entregado a su trabajo de auctor, sentado en el escritorio, en plena actividad (figs. 2, 3 y 4), o en actitud didác-

${ }^{15}$ M. ${ }^{\text {a }}$ J. Lacarra, «La fortuna del Ysopete en España», art. cit., págs. 112-113.

${ }^{16}$ L. Fischel, Bilderfolgen im frühen Buchdruck, op. cit., pág. 41. Más datos en M. Avery, «Miniatures of the Fables of Bidpai and the Life of Aesop», The Art Bulletin, 23, 1941, págs. 103-116. Véase también S. Obermaier, «Zum Verhältnis von Titelbild und Textprogramm in deutschschprachigen Fabelbüchern des späten Mittelalters und der frühen Neuzeit», GutenbergJahrbuch, 2002, págs. 63-75. 
tica, como corresponde a su obra (figs. 5 y 6). En algún caso, como en el ms. fr. 312 de la Bibliothèque Nationale de France (fig. 3), nuestro autor es representado con labios gruesos, nariz chata, pelo rizado, piel oscura, en lo que podría ser una referencia al origen nubio que se atribuía al esclavo ${ }^{17}$, pero la caracterización no va más allá y los miniaturistas no parecen ser conocedores de otros rasgos a los que se refiere la Vida, lo que no debe de sorprender, dada la tardía difusión de la obra de Planudes, que no alcanza el Occidente hasta mediados del siglo XV, gracias a Rinuccio, como hemos señalado más arriba. El retrato que abre la edición de Steinhöwel es, efectivamente, inhabitual, ya que no se conocían los datos contenidos en la Vida, pero podría remitir a modelos iconográficos de la tradición griega transmitida por Aviano.

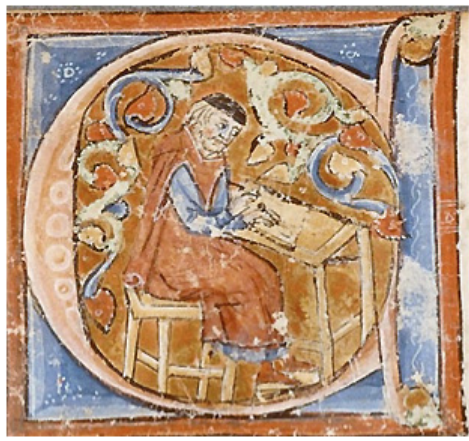

Fig. 2. BNF, ms. fr. 2173, fol. 58 .

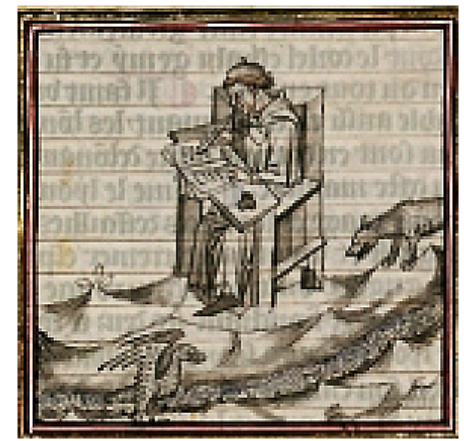

Fig. 3. BNF, ms. fr. 312, fol 124. Siglo XIII.

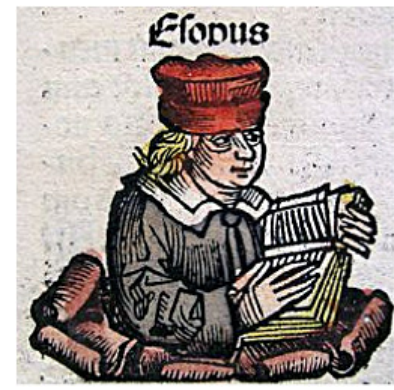
Año 1396.

Fig. 4. Hartmann Schedel, Weltchronik. Nüremberg, 1493.

${ }^{17}$ Se ha pensado con frecuencia que Loqmán, personaje preislámico similar a Esopo que aparece en el Corán (sura 31), recibe de su predecesor no pocos rasgos, entre otros el aspecto físico: nubio de gruesos labios y pies planos... y es un esclavo sabio. Otros datos en F. Rodríguez Adrados, De Esopo al Lazarillo. Huelva, Universidad, 2005, págs. 187-198. 


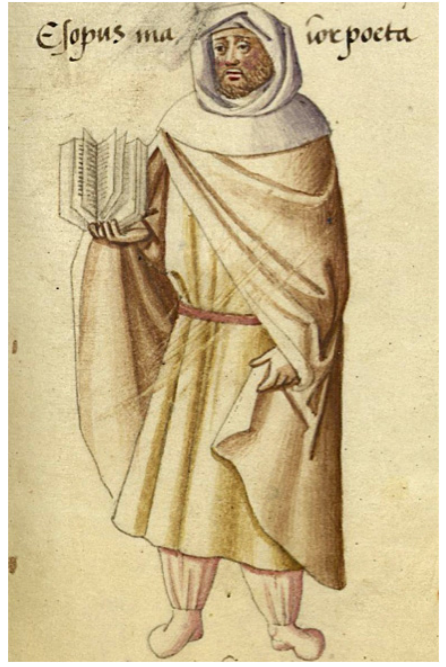

Fig. 5. BNF, ms.lat. 9673, fol. 15. Siglo XV-XVI

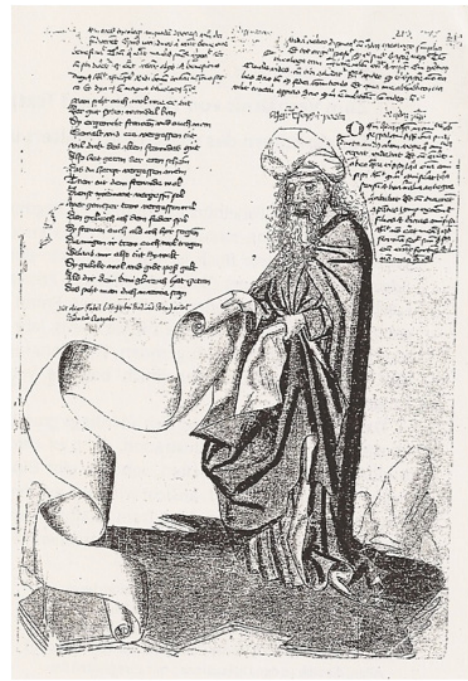

Fig. 6. Ulrich Boner, Der Edelstein. Munich, BSB, cgm 3974. Esopo.

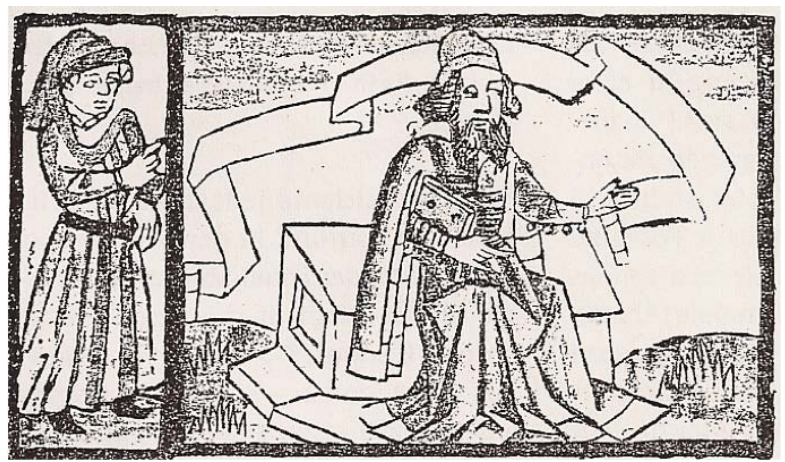

Fig. 7. Ulrich Boner, Der Edelstein. Bamberg, Albrecht Pfister, 1461. Narrador y autor.

Así, leemos en la versión castellana (Toulouse, 1488):

En las partes de Frigia donde es la antiquissima cibdad de Troya, avía una villa pequeña llamada Amonio en la cual nasció un moço diforme et feo de cara e de cuerpo más que ninguno que se fallasse en aquel tiempo, ca era de gran cabeça, de ojos agudos, de negro color, de maxillas luengas e de lengua tartamuda et çaçabilloso, et avía nombre Esopo ${ }^{18}$.

${ }^{18}$ Ed. Burrus-Goldberg, pág. 2. Modificamos las grafías. Todas las citas se refieren a esta edición. 
El conocimiento de la Vida de Planudes, y quizás de la tradición iconográfica de la rama griega, explica que nuestro fabulista aparezca de pie, con atuendo de esclavo, con los rasgos característicos de la deformidad física que le atribuye la biografía, y en actitud de dirigirse a un interlocutor.

La traducción francesa de Julien Macho, publicada en Lyon en 1480 y la castellana de Zaragoza (1489, y posiblemente también la de Zaragoza de 1482) utilizan el mismo grabado, dadas las relaciones comerciales existentes entre los impresores de estas ciudades y Johan Zainer, de Ulm ${ }^{19}$. Señala Carmen Navarro, siguiendo a Pere Bohigas, que Pablo Hurus se encontraba en Lyon el 7 de agosto de 1480 y la primera edición de la traducción de Julien Macho vio la luz en esta ciudad el 26 de agosto del mismo año; en febrero de 1484 el inquieto impresor zaragozano está otra vez en la ciudad francesa, y el 15 de mayo del mismo año vio la luz la segunda edición de la traducción de Julien $\mathrm{Macho}^{20}$. «El uso continuo y alternado de las mismas matrices en uno y otro país (1480, 1484, 1486 en Francia; 1482, 1489 en España) induce a pensar que probablemente se trate de uno de los múltiples contactos comerciales que Hurus mantenía con el extranjero» ${ }^{21}$.

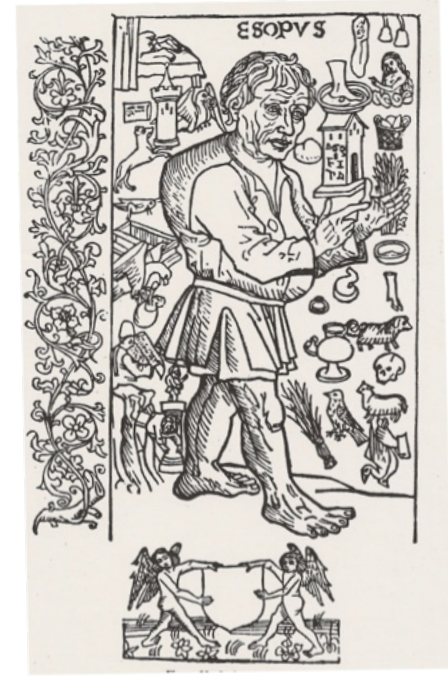

Fig. 8. Lyon, 1480.

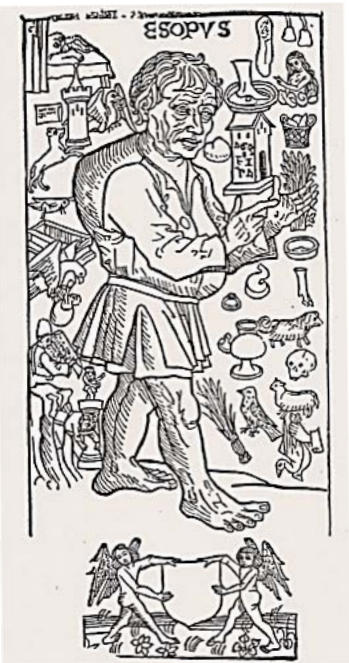

Fig. 9. Zaragoza, 1489.

\footnotetext{
${ }^{19}$ Algunos ejemplos se hallan en el trabajo de C. Navarro, «Notas a la iconografía del Isopete español», art. cit., págs. 550-551.

${ }^{20}$ C. Navarro, «Notas a la iconografía del Isopete español», art. cit., toma los datos de P. Bohigas, «La introducción de la tipografía en España. Estado actual de la cuestión», Biblioteconomía, 23, 1966, págs. 18 y sigs.

${ }^{21}$ C. Navarro, «Notas a la iconografía del Isopete español», art. cit., pág. 552.
} 
En ambos casos se aprecia sin dificultad la disposición de los símbolos que rodean la figura de Esopo distribuidos en tres columnas, una a la izquierda y dos a la derecha. La orla que adorna el grabado de Lyon es un elemento decorativo, aunque puede tener una función, como la de sujetar el taco o reforzarlo.

La edición en español de Toulouse copia invertida la ilustración y procura mantener la distribución de los símbolos, aunque el ilustrador no ha entendido alguno de ellos (el cuenco con la lenteja) y ha alterado el orden de los dos últimos (muerte y estatua).

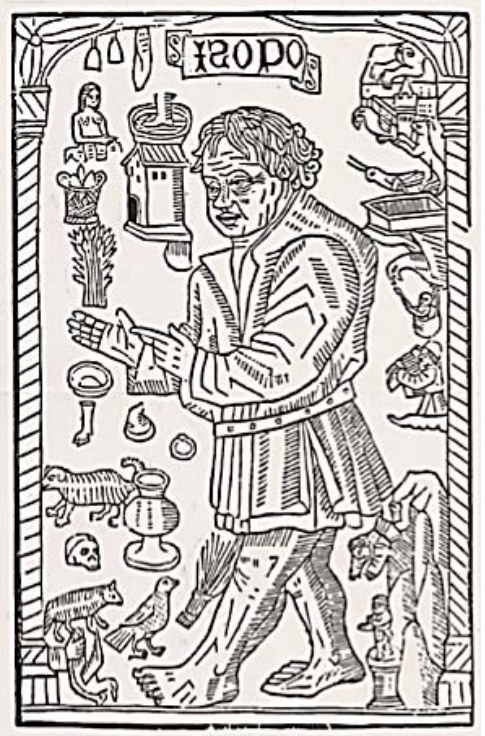

Fig. 10. Toulouse, 1488.

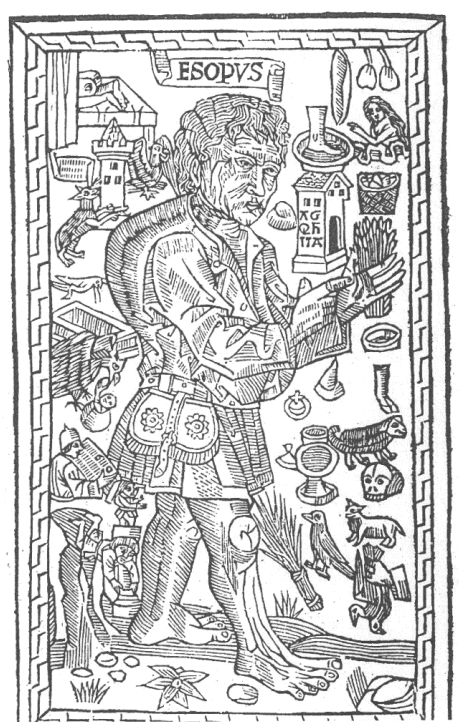

Fig. 11. Burgos, 1496.

\section{LOS SÍMBOLOS}

Ya hemos indicado que la primera página de la edición de las fábulas de Esopo impresa en Ulm en 1476/1477 constituye una novedad por el atuendo y la actitud del autor y por los rasgos físicos que le adjudica el artista que preparó la plancha. Es una novedad que no tarda en adquirir una rapidísima difusión en Francia y España, gracias a las relaciones comerciales existentes entre los impresores Zainer, Reinhard y Hurus; pero no se vuelve a encontrar un retrato similar, salvo la copia de Toulouse.

No menos extraña resulta la presencia de una treintena de elementos que se distribuyen en torno a la figura de Esopo. Si resulta difícil saber el origen o la inspiración del retrato del autor, no es más fácil establecer la genealogía del 
conjunto. No extraña, pues, que se hayan buscado raíces en la tradición escultórica de la Antigüedad tardía, especialmente en los sarcófagos en los que se representa al difunto rodeado de los símbolos correspondientes a su cargo o a su oficio.

Del mismo modo, se podría considerar la posibilidad de que esta primera página constituyera un programa del contenido o índice del libro; o dicho de otro modo, sería una especie de Ars memorativa, de sistema mnemotécnico para quien quisiera leer la obra o recordar lo leído; sin embargo, este planteamiento sólo es válido para la relación entre el grabado y la Vida de Esopo; el resto del contenido, las fábulas, que son el núcleo esencial, quedan fuera del programa, por lo que conviene acercarse a esta hipótesis con cierto escepticismo.

Por otra parte, podría plantearse que el impresor —o quizás el mismo Steinhöwel- quiso llevar a cabo un peculiar accessus ad auctorem; una presentación del autor de acuerdo con las normas escolares: se ha considerado la existencia de prólogos de tres tipos; el primero de ellos incluye antes de la obra el título, motivos e intención de la misma; y dentro del texto, el número de sus partes, el orden y el desarrollo. Este era el tipo de prólogo que generalizó ya en el siglo IV Donato (autor presente en los programas escolares) por sus comentarios a la Eneida. Otro de los paradigmas se aplicó al Paschale Carmen de Sedulio, el Virgilio cristiano, y a otros muchos poetas, entre los que se encontraba Ovidio con sus Metamorfosis: al frente de los textos hay que hablar de las circunstancias de su existencia, como son la vida del poeta, el título de la obra, la cualidad del poema, la intención del escritor, las divisiones internas, el orden de cada una de ellas, su desarrollo. El tercer tipo lo aplicó Remigio de Auxerre (h. 841-h. 908) a la obra de Marciano Capella basándose en las «circunstancias retóricas»: Quién, qué, Por qué, De qué modo, Dónde, Cuándo, Con qué intención $^{22}$. El «prefacio e prólogo del primero libro del Esopo» daba cuenta de todos estos aspectos, que por si fuera poco, quedaban reforzados por una «declaración de otro prólogo métrico» antes de dar paso a la primera de las fábulas. La incorporación de la Vida, desconocida hasta pocos años antes, venía a explicar quién era Esopo, y lo hacía añadiendo multitud de hechos significativos de su biografía. Es posible que el impresor, preocupado de continuo por establecer la relación entre las ilustraciones y el texto, se viera en la obligación de ilustrar esta primera parte del trabajo realizado por Steinhöwel. Aun así, desconocemos si existía ya algún manuscrito en el que se reunieran el retrato del autor y los símbolos de los acontecimientos más representativos de su vida.

Sabine Obermaier rechaza la hipótesis de que se trata de una xilografía introductoria de la Vida, dada su posición al frente del libro, dado su tamaño y

\footnotetext{
${ }^{22}$ La bibliografía es abundante, pero se puede encontrar material suficiente en A. J. Minnis, Medieval Theory of Authorship, 2nd ed., Aldershot, Wildwood House Ltd., 1988, págs. 9 y sigs.
} 
dado que en ella se establecería que Esopo era el autor de toda la obra, en contra de lo que se dice en el prólogo; podría tratarse de un cuadro que representara al protagonista, como ocurre en otras obras ${ }^{23}$.

Y aunque resulta difícil encontrar precedentes, pueden servir de orientación algunas representaciones bíblicas de la Creación, los sepulcros de la tardía Antigüedad (como ya hemos indicado), quizás algunos jeroglifos y, sobre todo, las representaciones manuscritas y tipográficas de las Arma Christi, que fueron tan populares a finales del siglo XV, asociadas o no a la Misa de San Gregorio ${ }^{24}$.

Las Arma Christi, o «armas de Cristo» son, ante todo, la expresión simbólica de la pasión de Jesucristo representada a través de los instrumentos utilizados en ella (corona de espinas, túnica, cruz, clavos, caña, esponja, lanza, etc.). La disposición de estos objetos en una panoplia daría lugar a un escudo de armas, las «armas de Cristo», que alegóricamente podrían ser interpretadas como las armas para vencer al demonio. Como conjunto iconográfico se encuentran ya desde el siglo IX en el Psalterio de Utrecht (830), obra maestra del arte carolingio y, como representante del mismo, con un profundo influjo bizantino. Será a partir del siglo XIV cuando se difunda el motivo iconográfico y cuando adquiera popularidad en el centro y norte de Europa, como prueba el poema Arma Christi en inglés medio. Sin duda, esa expansión se debió a la afluencia de reliquias que llegaron a Occidente gracias a las Cruzadas, de tal modo que no resultaba difícil encontrar algún objeto que hubiera estado en contacto con Jesucristo en sus momentos de mayor dolor.

Al tratarse de los objetos que causaron la pasión y muerte de Jesucristo, no tardó en asociarse a ellos la figura del «varón de dolores, familiarizado con el sufrimiento» ${ }^{25}$. También esta imagen del Vir dolorum procede de la iconografía religiosa de la Iglesia de Oriente. El conjunto no tardará en convertirse en la expresión más característica de la piedad de finales de la Edad Media ${ }^{26}$.

Por último, cuenta Jacobo de la Vorágine el milagro que se produjo durante una misa del papa Gregorio: al ir a dar de comulgar a una mujer ésta expresó su incredulidad acerca de la transformación del pan en la carne de Cristo; el papa se volvió al altar a rezar por aquella pecadora y cuando regresó para darle de comulgar, el pan se había transformado efectivamente en un trocito de

${ }^{23}$ S. Obermaier, «Titelbild und Textprogramm», art. cit., págs. 67-68.

${ }^{24}$ Para la tradición iconográfica del Vir dolorum y de las Arma Christi, véase G. Schiller, Ikonographie der christlichen Kunst. Vol. 2. Die Passion Jesu Christi, $2^{\mathrm{a}}$ ed., Gütersloh, Gütersloher Verlagshaus Mohn, 1983, págs. 198-243. S. Obermaier, «Titelbild und Textprogramm», art. cit., pág. 69, n. 24. Agradecemos a la Dra. Brigitte Roux, profesora del Departamento de Historia del Arte de la Université de Genève las sugerencias que nos hizo al respecto.

${ }^{25}$ Isaías 53, 3. La expresión de Isaías dará lugar a la imagen de Jesús, víctima de todos los suplicios, frecuentemente asociada a las Arma Christi.

${ }^{26}$ G. Schiller, Ikonographie der christlichen Kunst, op. cit., págs. 212 y sigs. y, en especial las ilustraciones 681-812. 
carne $^{27}$. El milagro se conoce al menos desde el siglo VIII, pero entre la popularidad de la obra de Vorágine y la preocupación de la Iglesia por hacer creer a los fieles en el misterio de la Transubstanciación, el trocito de carne del tamaño de un dedo iría ampliándose a una visión más compleja, confluyendo con la imagen del Vir dolorum y de las Arma Christi. Es muy posible que la difusión de esta iconografía surgiera en Roma a raíz del Jubileo de 1350: los peregrinos podían contemplar en la basílica de la Santa Cruz de Jerusalén (en Roma) un mosaico bizantino que atestiguaría la veracidad del milagro y que mostraba una imagen característica del Vir dolorum. Al parecer, las más antiguas representaciones pictóricas de la Misa de San Gregorio se situarían en ámbito alemán en torno al año $1430^{28}$.

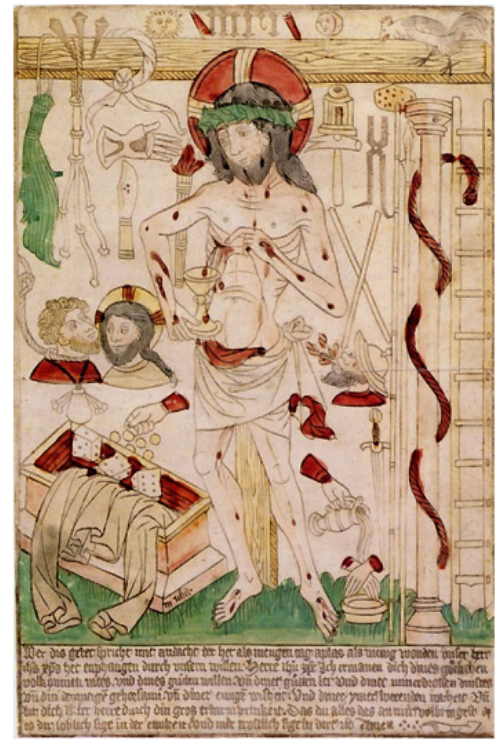

Fig. 12. Vir dolorum con las Armas de Cristo. Nüremberg, 1470/1488. Germanisches Nationalmuseum.

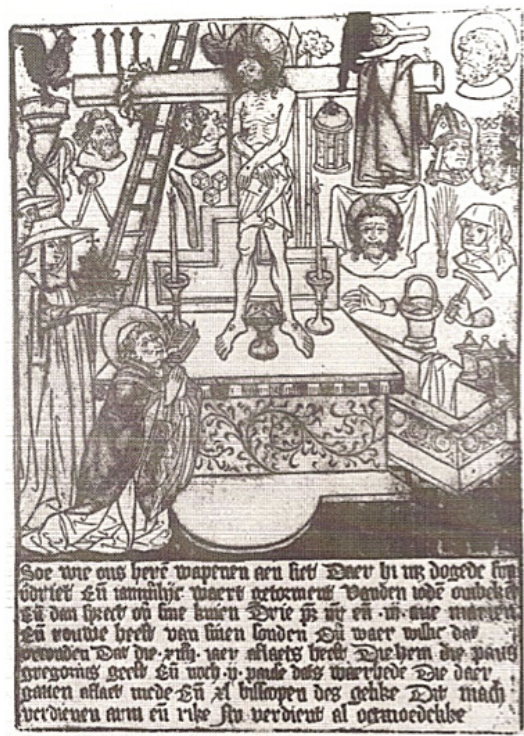

Fig. 13. Misa de San Gregorio.

Hacia 1462. Nüremberg, Germanisches Nationalmuseum ${ }^{29}$.

Así, el frontispicio de las fábulas de Esopo en la edición alemana de Steinhöwel podría ser deudor de una estructura derivada de la iconografía po-

${ }^{27}$ Leyenda dorada, cap. 46, § 11.

${ }^{28}$ G. Schiller, Ikonographie der christlichen Kunst, op. cit., págs. 240 y sigs.

${ }^{29}$ La xilografía de la Misa de San Gregorio copia la miniatura del mismo tema de un manuscrito de Wolfenbüttel, fechado poco antes, hacia 1456. La posición de los brazos y las manos muestra un claro origen bizantino; en la fig. 12 la postura ha cambiado, de acuerdo con modelos occidentales, tal vez italianos. 
pular de las Arma Christi, pero es evidente que la inspiración se detiene en la estructura.

Si consideramos el carácter cómico de la Vida de Esopo y la proximidad de las ilustraciones y el texto, se puede aceptar una presentación jocosa que en modo alguno pretendería denigrar la obra, sino facilitar la proximidad de la misma al lector, que a través de esta primera ilustración podía apreciar el sermo humilis del contenido, a pesar del bilingüismo con que se presentaban las conocidas fábulas.

Volvamos al retrato y detengámonos en los símbolos que acompañan al caminante. La lectura iconográfica comienza por la esquina superior derecha y desciende a lo largo de toda la columna; a continuación continúa con la segunda columna de ese mismo lado y sigue en orden descendente; por último, la columna de la izquierda relataría los episodios finales de la vida de Esopo. Se muestra, pues, una clara relación con el contenido, no sólo por los elementos seleccionados, sino también por el orden que mantienen ${ }^{30}$.

Por lo general, los símbolos se encuentran en la ilustración que acompaña el episodio correspondiente de la biografía del fabulista, de forma que en el frontispicio el grabador no ha hecho sino aislar el detalle. No obstante, en ocasiones no se encuentra ilustrado el episodio y, en este caso, el grabador ha inventado el símbolo; mientras que en otras ocasiones se han producido cambios que indicaremos en el momento oportuno.

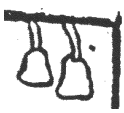

Agathopus, tomando los figos e mirando aquellos, la cubdicia desordenada de la gula se acrescentó en él, et assí andando remirando los figos delante un compañero suyo, dos de aquellos se comió ${ }^{31}$.

Esopo, acusado por sus compañeros de esclavitud, vomita el contenido de su estómago, que estaba vacío, mientras que Agathopus al tener que hacer lo mismo queda en evidencia. La ilustración no representa los higos, sino que se limita a recoger la escena en la que Agathopus devuelve lo que había comido.

Como la diosa de la piedad et caridad uviesse oído et entendido las plegarias de Ysidis, aparesció al Esopo et dio le en gracia que pudiesse fablar distintamente et sin ningún impedimento todas las fablas de las gentes et que entendiesse los cantares de las aves et las señales de los animales et que dende adelante fuesse inventor et recitador de muchas et varias fábulas ${ }^{32}$.

\footnotetext{
${ }^{30}$ S. Obermaier, «Zum Verhältnis von Titelbild und Textprogramm», art. cit., pág. 66 presenta un cuadro con la relación de estas ilustraciones con el texto del Esopus de Steinhöwel y hace breves comentarios en pág. 67.

31 Los textos proceden de la edición citada de V. A. Burrus y H. Goldberg; indicaremos la página. Modificamos grafías y puntuación. Pág. 2a.

32 Pág. 3b. La diosa debe identificarse con Isis.
} 
Uno de los rasgos de Esopo era su tartamudez, que pierde como don de la «diosa de la piedad», porque había tratado con compasión al sacerdote Ysidis; éste, agradecido, pide a los dioses que premien su hospitalidad. La diosa se presenta en un sueño, a la hora de la siesta, y no puede ser de otra manera, pues la tradición así lo exigía ${ }^{33}$. Tanto el motivo de la recuperación del habla, como el de la hospitalidad recompensada son frecuentes. La comprensión del lenguaje de los animales da lugar a cuentos como el del «niño que entendía a los pájaros», de raíces hindúes ${ }^{34}$.

En el grabado, la diosa aparece en actitud mayestática, de medio cuerpo, de frente y con una especie de cetro o bastón en la mano derecha, en un nimbo que podría ser de nubes.

El Esopo, mirando todo cuanto era de levar en el viaje, es a saber, los sacos, costales, fardaje et canastos, tomó una canasta cargada de pan que estava por carga para $\operatorname{dos}^{35}$.

A medida que pasaban los días, la carga de Esopo se iba haciendo más ligera y llevadera, pues entre todos comían el pan. Lo que en principio pareció una locura a los compañeros, no tardó en convertirse en una muestra de astucia $^{36}$.

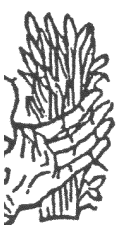

De gracia te do las verduras et cuando las ovieres menester vendrás et toma de gracia cualquier cosa de la huerta ${ }^{37}$.

Esopo acompaña a su amo Xanthus a comprar verduras. El hortelano plantea una cuestión que Xanthus es incapaz de resolver, ¿por qué las plantas silvestres crecen antes y con más rapidez que las cultivadas? Esopo da una respuesta que satisface al vendedor; éste, agradecido porque le ha saciado la curiosidad, le regala las verduras ${ }^{38}$.

33 J. Acebrón Ruiz, «No entendades que es sueño, mas vyssión çierta. De las visiones medievales a la revitalización de los sueños en las historias fingidas», en R. Beltrán, ed., Literatura de caballerías y orígenes de la novela, Valencia, Universitat, 1998, págs. 249-257. C. Alvar, «Sañudo e non con vino. (Libro de buen amor, 181b)», en R. Alemany, J. LL. Martos y J. M. Manzanaro, eds., Actes del X Congrés Internacional de l'Associació Hispànica de Literatura Medieval, Alicante, Institut Interuniversitari de Filologia Valenciana, 2005, págs. 265-272.

34 S. Thompson, Motif-Index of Folk Literature. 6 vols., Bloomington, Indiana UP, 19551958, V221.2; D1815.2. El cuento del «niño que entendía el lenguaje de los pájaros» se encuentra en algunas versiones de Los siete sabios de Roma y no tarda en cruzarse con la leyenda de Amís y Amiles. Cfr. C. Alvar y H. O. Bizzarri, Amís y Amiles. Cantar de gesta francés del siglo XIII y textos afines, Turnhout, Brepols, 2010.

35 Pág. 5a.

${ }^{36}$ S. Thompson, Motif-Index, op. cit., W111.2.0.1 y J1114.0.1 son motivos que aluden a la astucia del esclavo.

37 Pág. 9b.

${ }^{38}$ S. Thompson, Motif-Index, op. cit., J1033 recoge el Motivo del hortelano. 
El Esopo saca con la cuchar la lenteja que avía puesto a cozer de la caldera et tráhela a la mesa ${ }^{39}$.

Xanthus había ordenado a Esopo que preparara «lenteja» para comer; el esclavo coció una sola lenteja, ateniéndose a la forma del singular utilizada por su amo, ante el estupor de los comensales y la indignación del señor ${ }^{40}$. La lenteja se reconoce sin dificultad en la edición de Ulm, pero ni en Lyon, ni en Zaragoza se puede distinguir la leguminosa, quizás por deterioro de la matriz; para mayor claridad en la exposición, hemos recurrido al símbolo según aparece en la edición de Steinhöwel, y según se representa en el grabado del episodio correspondiente.

El Esopo, catando la olla, como falló solamente tres pies et pensando la cosa como avía acaescido, descendió al establo et cortó un pie al puerco que ende era et tornando arriba, púsolo en la olla ${ }^{41}$.

Se trata de la continuación del episodio anterior; para que los invitados puedan comer, Xanthus manda a Esopo a comprar y preparar cuatro manos de cerdo; pero encolerizado con su esclavo busca un motivo para azotarlo y como no lo encuentra, saca de la olla una de las manos; el astuto servidor se da cuenta de la jugada y corta un pie al cerdo de la casa, pero cuando lo va a poner en la olla se encuentra con que el señor ha restituido el anterior, de manera que a la hora de servir hay cinco y no cuatro manos de animal, para nueva sorpresa de los comensales ${ }^{42}$.

El grabado del episodio deja bien de manifiesto un plato con una lenteja, una fuente en la que hay cinco patas de cerdo, que lleva Esopo, y el animal mutilado tras él.

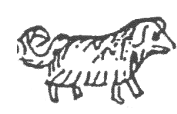

E la perrilla, falagando con la cola, vino al olor de las viandas ${ }^{43}$.

Xanthus envía una parte de la cena a su «bienqueriente» mediante Esopo, que aprovecha la ocasión para burlarse de la mujer de su amo. En vez de darle a ella la comida, se la da a la perra, que al parecer del esclavo quería más a su dueño que la mujer ${ }^{44}$.

\footnotetext{
39 Pág. 10a.

${ }^{40}$ S. Thompson, Motif-Index, op. cit., J2469.1 recoge el motivo de la lenteja en la sopa, dentro de una serie de motivos referidos a las instrucciones que se siguen literalmente.

41 Pág. 10b.

${ }^{42}$ S. Thompson, Motif-Index, op. cit., K2155, muestra al engañador burlado.

43 Pág. 11a.

${ }^{44}$ Se repite el motivo de las instrucciones que se siguen al pie de la letra.
} 
Uno dellos demandó en qué tiempo sería mayor priessa et dificultad a los ombres. El Esopo, presto de ingenio, el cual estava tras los otros, respondió: - Cuando los muertos en la resurreción cada uno buscará su cuerpo ${ }^{45}$.

Demandó otro por qué las animalias como son traídas para matar, calladamente vienen et non dan boz alguna, et el puerco nin solamente se dexa tomar, mas de continuo grueñe et regaña [...] El Esopo, como de cabo, responde:

- Como los ganados así como vacas et ovejas et otras animalias sean acostumbradas a se ordeñar et tresquillar, vienen callando porque piensan que vienen para aquello et assí non han miedo del fierro ${ }^{46}$.

Las preguntas son planteadas por los discípulos de Xanthus a continuación de la cena y del episodio de la perrilla; estas cuestiones constituyen un paréntesis en el episodio de la perrilla, pues continuará poco más adelante con el reencuentro de Xanthus y su esposa.

Nada hay en el incunable que haga pensar en una representación gráfica de la calavera, ni de los animales a los que alude el episodio.

Tomó dineros et vase otro día al mercado et compró gallinas, capones, pabones et anseres ${ }^{47}$.

Enfadada por el trato recibido del esclavo y de su marido, la mujer de Xanthus decide abandonar el hogar y no acepta regresar por más que le insiste el filósofo. Ante esta situación, Esopo simula que su amo va a volver a casarse y para ello compra buenos manjares y lo hace saber a un criado de su señora, que no tarda en ponerlo en conocimiento de la mujer. Ésta acude de inmediato a su antigua casa, encolerizada ante la idea de que Xanthus tomara nueva esposa.

El grabado correspondiente muestra a Esopo con una cesta con pollos de ganso y dos aves adultas en brazos del protagonista, que habla ante un joven, mientras son observados desde una ventana por una mujer.

Termina aquí la primera columna de las ilustraciones y comienza la segunda con la imagen de una lengua colgada:

Fuese a la carnecería et compró solamente lenguas de puercos et aquellas guisó et puso la mesa ${ }^{48}$.

El festín de Esopo es uno de los episodios más conocidos de la «vida» del fabulista: Xanthus le encarga un manjar «muy bueno et

\footnotetext{
${ }^{45}$ Pág. 11a.

${ }^{46}$ Pág. 11b. S. Thompson, Motif-Index, op. cit., J 1733, acerca de la loca ignorancia.

${ }^{47}$ Pág. 12a-b.

${ }^{48}$ Págs. 12-13.
} 
muy dulce et sabroso» para agasajar a sus discípulos; por tres veces sirve lengua de cerdo, condimentada de forma diferente, con vinagre y con sal de pimienta y ajos. Esopo explica que no hay motivo para la indignación de su señor, pues no hay nada mejor que la lengua, que sirve para dar, tomar, saludar y para toda relación entre las personas. El día siguiente Xanthus le encarga lo peor y más magro; y el esclavo vuelve a comprar y servir lengua, con la misma salsa que el día anterior. Ante el enfado del amo, Esopo explica que por la lengua perecen los hombres, llegan a la pobreza y se destruyen las ciudades.

El asunto tiene una amplia difusión, aunque el objeto puede ser el corazón, en vez de la lengua; la forma de condimentar el manjar podría tener carácter simbólico, como señalan Burrus y Goldberg en su edición (p. 29, n. 24).

Aunque en el frontispicio parece que la lengua está expuesta en la carnicería, el grabado representa la escena del banquete, con las lenguas en la fuente de servir.

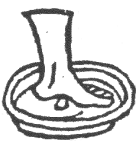

E ella, como el marido le mandó, puso un bacín de agua a los pies del aldeano. El cual [...] se dexa lavar della los pies, et bien lavado, folgó ${ }^{49}$.

De nuevo, el engañador es burlado. Xanthus intenta encontrar motivos para castigar a Esopo; por orden del filósofo, el esclavo busca a un hombre desaliñado y desprovisto de curiosidad, para que vaya a comer a casa de su señor; éste prepara una trampa para poder llevar a cabo sus propósitos, y para ello manda a su mujer que lave los pies del invitado, esperando que éste rechazaría semejante honor $\mathrm{y}$, por lo tanto daría muestras de curiosidad por lo que Xanthus podría castigar a Esopo que no habría cumplido con exactitud su encargo; pero no fue así, de manera que el señor y su mujer quedaron burlados.

Yendo el Esopo al baño donde estava grand compaña, vio que todos los que entravan et salían se lijavan en los pies a una piedra. Finalmente, uno que estava assentado a la puerta del baño, como se feriesse al pie en aquella piedra, quitándola dende, púsola a parte ${ }^{50}$.

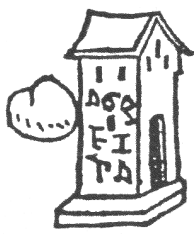

La ilustración está compuesta por dos elementos: el edificio y, a su izquierda, la piedra, debidamente apartada del lugar de paso, para que no vuelvan a tropezar quienes acuden a los baños. Sólo uno fue capaz de pensar y decidir retirar la piedra; sólo él actuó como hombre, de forma que cuando Xanthus se enfadó porque Esopo le había dicho que había visto un solo hombre en los baños, éste le dio la explicación de por qué no consideraba hombres a los demás.

\footnotetext{
49 Pág. 13.

50 Pág. 14.
} 
El episodio no está ilustrado en el incunable.

5 -Dime, ¿por qué los hombres cuando salen fuera et limpian su vientre miran luego su estiércol? $?^{51}$

Ante la pregunta de Xanthus, Esopo contesta que en cierta ocasión un sabio echó juntos los sesos y las heces, y desde entonces la gente mira el estiércol, pero Xanthus no debe temer, «pues lo que no tiene, no puede perderlo» ${ }^{52}$.

Apostaron sobre esto, poniendo los anillos por señal et fuéronse cada uno para su casa ${ }^{53}$.

El filósofo asentado en su silla manda lavar la taça et que fuesse traída llena de agua $^{54}$.

Habiendo bebido más de la cuenta, Xanthus apostó con un discípulo suyo que era capaz de beberse el agua del mar; en señal de la

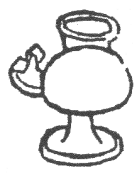
apuesta deja el anillo. Al día siguiente, al despertar y no ver el anillo en su dedo, se entera de lo ocurrido la víspera. Esopo lo salva al sugerirle que exija a su contrario que impida que los ríos viertan su caudal al mar mientras él realiza la apuesta. La imposibilidad de las dos tareas deja en empate la apuesta ${ }^{55}$.

El grabado no presenta referencia al anillo, pero sí a la vasija, que un criado está llenando con agua del mar en presencia de Esopo.

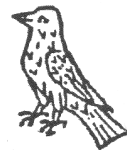

El Esopo salendo de casa, como viesse dos cuervos que estavan en un árbor, luego lo contó al señor ${ }^{56}$.

Mandólo despojar et que fuesse açotado sin mesura ${ }^{57}$.

Nuevo enfrentamiento entre amo y siervo. Xanthus pide a Esopo que le avise si ve dos cuervos, y éste así lo hace, pero en el rato que va a avisarle, una de las dos aves levanta el vuelo. Cuando Xanthus llega al lugar se encuentra con un solo cuervo, signo de mal agüero, en vez de los dos que le

\footnotetext{
51 Pág. 14-15.

${ }^{52} \mathrm{El}$ motivo se encuentra aplicado a animales, como el asno, en S. Thompson, Motif-Index, op. cit., A 2495.2 .

53 Pág. 15.

${ }^{54}$ Pág. 15 b.

55 Es un tema frecuente en el folclore: S. Thompson, Motif-Index, op. cit., H696.1.1, H1142.3, J1161.9. Una tarea similar se encuentra en los Bocados de oro, ed. M. Crombach. Bonn, Universität, 1971, págs. 146-147 y en El libro de los Engaños, ed. J. E. Keller, Chapel Hill, Univ. of North Carolina, 1959, págs. 58-62.

56 Pág. 16a.

57 Pág. 16a.
} 
hubieran proporcionado buena suerte ${ }^{58}$. La disputa entre señor y criado termina con un severo castigo contra éste, que es azotado.

La xilografía del incunable representa a uno de los cuervos sobre un árbol, mientras que el otro ha levantado el vuelo. Esopo, sin vestiduras, es azotado con un haz de ramas muy similar al que aparece en el frontispicio.

Termina aquí la segunda columna de símbolos y comienza la serie que queda situada a la izquierda de la imagen de Esopo.

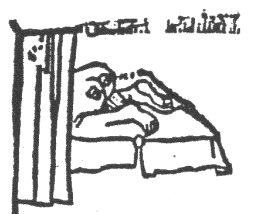

Fallándola como veis dormiendo, caladamente le descubrí aquellas partes porque los ojos que tenía en ellas pudiessen ver la mesa puesta $^{59}$.

Un día que Esopo se disponía a preparar la comida, vio a la mujer de su amo durmiendo dentro de la habitación y le pidió que cuidara de todo, no fuera a comerlo el perro, a lo que la señora le contestó que hasta sus nalgas tendrían ojos para vigilar. Otro día que la encontró durmiendo con «las partes traseras faz a la mesa», se acordó de la frase que le había dicho, y entonces le levantó las faldas y la dejó dormir con las nalgas descubiertas mirando a la mesa. Xanthus al llegar preguntó qué era aquello y Esopo le explicó que le había levantado las faldas para que los ojos pudieran ver la mesa... ${ }^{60}$

La ilustración del incunable es un conjunto en el que aparecen Xanthus y Esopo en la puerta de la sala, la mesa dispuesta para la comida, y la mujer de Xanthus durmiendo en la cama. El grabador no ha sido capaz de representar con claridad los detalles de la escabrosa situación, aunque en las nalgas de la dama hay una marca que podría intentar ser un ojo.

Es posible que haya que analizar como un solo conjunto las dos imágenes siguientes: es claro que se trata de un rótulo o un cartel y de una construcción; lo que no resulta tan evidente es qué simboliza la construcción y del significado que le demos dependerá el del letrero que hay a su lado.

Tras la burla de las nalgas, el texto de la Vida incluye un episodio en el que Xanthus encarga a Esopo que haga de portero en su casa, y que no deje entrar a «ningún idiota et sin letras, mas tan solamente a los filósofos et retóricos», de tal forma que el esclavo se convierte en el juez de los conocimientos de los invitados de su señor. Como era previsible, sólo dejará pasar a una persona, el único que entiende lo que le dice ${ }^{61}$.

58 A. Galmés de Fuentes, La épica románica y la tradición árabe, Madrid, Gredos, 2002, págs. 501-511 estudia el tema de los agüeros según la posición o la dirección del vuelo de las aves. Es un tema poco conocido en la literatura románica medieval.

59 Pág. 16 a-b.

${ }^{60}$ S. Thompson, Motif-Index, op. cit., D 1317.1.

${ }^{61}$ Pág. 16-17. 
Es evidente que hay un elemento, la casa de Xanthus, que podría haber inspirado el símbolo que aparece en el frontispicio que estamos analizando, y entonces el rótulo sería independiente de la torre.

Inmediatamente después de este episodio, Xanthus y su esclavo están ante la tumba de los antepasados; el señor lee las letras del epitafio y Esopo ve cerca de allí otras letras:

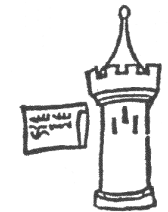

Como Xantus con Esopo en las sepulturas de los mayores fuesse et Xanthus las letras del epitafio de la sepultura leyesse, el Esopo en una arca que estava cerca de la estatua a la cual por las gradas se subía vio unas letras non sonantes mas solamente por puntos pintadas et esculpidas $^{62} \ldots$

El filósofo es incapaz de entender las letras, pues son solo las iniciales de un texto en latín, que el esclavo interpreta correctamente, encontrando el tesoro oculto. Lo mismo ocurre en otras dos ocasiones. El episodio habla de un monumento fúnebre con escalones, que puede haber sido representado mediante una torre, y de un letrero (o tres carteles, para mayor exactitud), que han sido simbolizados con claridad en la xilografía mediante un solo elemento. Señalan V. A. Burrus y H. Goldberg que tanto el texto alemán como el incunable castellano derivado de él hablan de tres series distintas de letras, mientras que el original presenta una serie de letras en griego que son interpretadas de tres formas distintas. Steinhöwel en su versión latina dejó en blanco el espacio para las palabras griegas, pero en la versión alemana prescindió del griego y en su lugar recurrió a las tres series que serían traducidas al español (el traductor utilizó aquí el texto alemán y no el latino). Julien Macho y el traductor inglés, William Caxton, que utiliza la versión francesa de Macho mantuvieron la transliteración de las letras griegas para los dos primeros mensajes, pero en el tercero pasaron al latín 63 .

En todo caso, parece que este episodio es mucho más relevante que el precedente y, por lo tanto, consideramos asociadas la torre y el letrero, como una sola unidad.

A continuación, el incunable incluye un grabado que no tiene símbolo en el frontispicio: Esopo está encarcelado y con los pies en grilletes.

En este mesmo tiempo, cosa muy marabillosa acaesció en ese lugar de Samun, en el cual, como se fiziessen juegos públicos, una águila de una volada súbitamente el anillo del juez et inquisidor mayor arrebató del teatro, o lugar donde se fazen los espectáculos, el cual anillo dexó caher en el seno de un esclavo ${ }^{64}$.

\footnotetext{
${ }^{62}$ Pág. 17 a-b.

${ }^{63}$ Burrus y Goldberg, pág. 30, núm. 32.

${ }^{64}$ Págs. 17b-18a.
} 
Esopo consigue la libertad a cambio de la interpretación de este hecho maravilloso, en el que el águila simboliza a un rey o alto señor, pues es la reina de las aves.

Creemos que merece la pena señalar que el ilustrador del incunable, siempre minucioso y dado a enriquecer las ilustraciones con detalles de todo tipo, representa en la xilografía del episodio al águila que acaba de soltar el anillo, mientras que los personajes (hasta siete podemos contar en el grabado) se encuentran en el teatro, según indica el texto. Sin embargo, no hay ninguna construcción que haga pensar en un teatro, ni nada que se le asemeje, lo que deja patente el escaso conocimiento que había a finales de la Edad Media de qué era un teatro y cuál era su forma; bastará leer que el autor (y el traductor) han tenido que aclarar que «teatro» es el «lugar donde se fazen los espectáculos». Pero no es éste el momento para entrar en la debatida cuestión del teatro medieval, de la que se ha ocupado con la maestría que le caracteriza Ángel Gómez Moreno65.

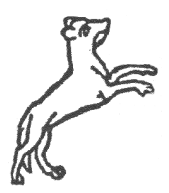

Los lobos movieron guerra contra las ovejas, las cuales non se pudiendo defender dellos demandaron favor et ayuda de los perros, los cuales guerreando e impugnando contra los lobos fiziéronlos fuir ${ }^{66}$.

La interpretación que había dado Esopo al episodio del águila y el anillo hablaba de la amenaza que se cernía sobre los habitantes de Samun, ciudad codiciada por el rey Cresus. Este rey no tardó en invitar a Esopo a que fuera a verlo y el liberto, temiendo el peligro, explicó la situación a los habitantes de Samun con la fábula de las ovejas y los lobos, que se recoge en el propio Isopete (III, 13) y que es un motivo de amplia difusión en el folclore, quizás debido a su presencia en colecciones de exempla destinados a la predicación, o en los propios sermones, como es el caso de Jacques de Vitry ${ }^{67}$.

65 A. Gómez Moreno, El teatro medieval castellano en su marco románico, Madrid, Taurus, 1991. Para el teatro medieval en general, véase C. J. Stratman, Bibliography of Medieval Drama, 2 vols., $2^{a}$ ed., New York, Ungar, 1972; véanse, además, los libros clásicos de E. K. Chambers, The Medieval Stage, 2 vols., Oxford, Clarendon Press, 1903; de G. Frank, The Medieval French Drama, Oxford, Clarendon Press, 1954; de R. Menéndez Pidal, Poesía juglaresca y orígenes de la literaturas románicas, Madrid, Instituto de estudios políticos, 1957; de E. Faral, Les jongleurs en France au Moyen Âge, Paris, Champion, 1964; de H. López Morales, Tradición y creación en los orígenes del teatro castellano, Madrid, Ediciones Alcalá, 1968; y de M. A. Pérez Priego, Teatro medieval, 2. Castilla, Barcelona, Crítica, 1997.

66 Pág. $19 b$.

${ }^{67}$ S. Thompson, Motif-Index, op. cit., K.191, B267.2, etc. Para la presencia en textos de carácter religioso, cfr. F. C. Tubach, Index exemplorum. A Handbook of Medieval Religious Tales, Helsinki, Academia Scientiarum Fennica, 1981, núm. 5357. Para Jacques de Vitry, véase Th. F. Crane, The Exempla or Illustrative Stories from the «Sermones Vulgares» of Jacques de Vitry, London, The Folk-Lore Society, 1890 [Nendeln, Kraus Reprint, 1967], núm. 45. 
Un ombre pobre, andando a caça de langostas, prendió et caçó una cigarra ${ }^{68}$.

Se trata del exemplum que utiliza Esopo para defenderse ante el rey Cresus. La cigarra se arguye ante el cazador de langostas diciendo que no causa daño, sino que sólo canta. El rey, movido por la sabiduría de su prisionero, lo deja en libertad; éste pide que no haga daño a los de Samun.

Hermipo, que uvo piedad d'él, mirando et considerando que podía aprovechar por algún tiempo con estudio, non lo fizo matar, antes ascondidamente lo metió en un sepulcro et allí lo tuvo et guardó vivo ${ }^{69}$.

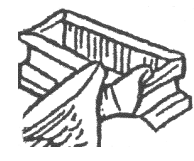

Esopo, traicionado por su hijo adoptivo Enus ante el rey Licurus de Babilonia, es acusado de querer ir a resolver los enigmas de otros reyes, motivo por el que Licurus manda a su caballero Hemipo que le dé la muerte.

El exemplum de las cigarras no está ilustrado en el incunable, mientras que la tumba es más bien una cueva en la que un joven introduce a Esopo.

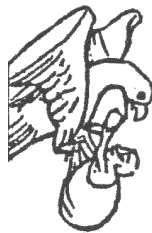

Llamados los falconeros, mandóles el Esopo que pollos fijos de águilas tomassen, los cuales como fuessen tomados, acostumbrólos cebar et comer andando arriba et baxo volando, ligadas et atadas a los pies unas talegas de cuero en cada una de las cuales estava un niño. E assí como los niños alçavan o abaxavan el cebo, assí las áquilas seguiendo el cebo et comer bolavan arriba o baxo ${ }^{70}$.

Cuando el rey Nectanabo de Egipto se enteró de la «muerte» de Esopo, envió un enigma a Licurus, que consistía en cómo edificar una torre que no tocara en el cielo ni en la tierra. Si Licurus es capaz de responder, el egipcio le pagará tributo durante diez años. La reaparición de Esopo supone la solución del problema mediante un recurso que recuerda el utilizado por Alejandro Magno para explorar el cielo; es muy posible que el episodio contenido en la biografía de este rey inspirara abundantes relatos de carácter más o menos folclórico $^{71}$.

Et otro día de mañana traxo et monstró ante el rey aquella escriptura, la cual leída, el rey marabillado se dize a los suos ricos ombres ${ }^{72} \ldots$

El rey Nectanabo de Egipto está convencido de la superioridad de Licurus de Babilonia, que es capaz — gracias a Esopo— de resolver

${ }^{68}$ Págs. 19b-20a.

${ }^{69}$ Pág. 20b.

${ }^{70}$ Págs. 21b-22a.

${ }^{71}$ S. Thompson, Motif-Index, op. cit., B542.1 y B552.1, F982.1; F. C. Tubach, Index exemplorum, núm. 125.

${ }^{72}$ Pág. 23a. 
cuantos enigmas y cuestiones le plantea. Antes de pagar el tributo acordado, deciden hacerle una última pregunta: «¿Qué cosa es la que nunca oímos nin vimos?». La respuesta ingeniosa de Esopo representa su último gran triunfo. Se trataría de la falsa carta de una deuda inexistente de mil marcos de plata que habría recibido el rey Nectanabo del rey Licurus. Al ser todo falso, el rey Nectanabo y sus consejeros tienen que reconocer que nunca oyeron ni vieron nada al respecto. Esopo consigue de este modo que el rey conteste al último enigma.

Nada hay en el grabado que haga pensar en la carta de la deuda del rey Licurus.

De regreso a Babilonia, le harán una gran estatua de oro.

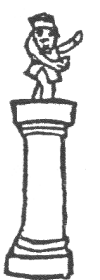

Por lo cual el rey mandó que fuesse fecha al Esopo imagen de oro en público $^{73}$.

Lilli Fischel ha señalado que la estatua, que casi no se puede ver, elevada sobre una columna, tiene exactamente la misma postura que el gran retrato de Esopo en la página inicial de la edición de Steinhöwel, y que ambas representaciones parecen remitir a las estatuas hechas por Lisipo (siglo IV a. C.) y por su discípulo Aristodemos ${ }^{74}$.

Tras el éxito en Babilonia, Esopo decidió conocer otras tierras. En Delfin (Delfos) tuvo enfrentamientos con los habitantes, que lo acusaron injustamente de haber robado una copa del templo de Apolo.

Mas ellos, non curando de le oír nada, de una peña áspera lo fizieron despeñar et caher et así el coitado del Esopo finesció su vida ${ }^{75}$.

Tres grabados ilustran en el incunable el final de la vida de Esopo: la acusación del robo de la copa, las discusiones con los

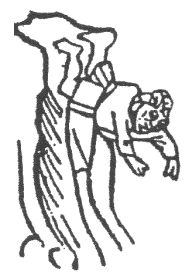
habitantes de Delfos y la muerte del filósofo, empujado desde una alta roca, ante numeroso público.

De nada le sirvieron ya sus ejemplos, sus salidas ingeniosas, su sarcasmo o su mordacidad, pues se enfrentaba no a «ombres claros et ilustres, mas de siervos inútiles et perversos soy muerto».

\footnotetext{
${ }^{73}$ Pág. 23b.

${ }^{74}$ L. Fischel, Bilderfolgen im frühen Buchdruck, op. cit., pág. 42 y núm. 54.

75 Pág. 25.
} 


\section{CONCLUSIÓN}

Las fábulas de Esopo llegan a la literatura medieval por dos caminos diferentes: el trazado por Fedro y el marcado por Aviano. Pero no se trata de dos caminos equiparables: Fedro tuvo una amplia descendencia gracias a las reelaboraciones de Romulus y de Gualterius Anglicus, mientras que Aviano y otros parientes de la versión griega de Babrio quedaron relegados a un segundo plano. En todo caso, la popularidad de las fábulas fue grande a lo largo de toda la Edad Media, debido a la presencia de estos breves textos didácticos y moralizantes en las escuelas como método sencillo para dar los primeros pasos en latín. Y así transcurrieron los siglos «oscuros» sin grandes alteraciones: Esopo era un maestro, un auctor, cuyo prestigio se imponía sobre cualquier otra consideración, pero nada se sabía de este escritor, a no ser de forma indirecta y fragmentada, inconsistente. No extraña, pues, que cuando Rinuccio d'Arezzo pone en circulación a mediados del siglo XV la traducción en latín de la vida de Esopo escrita por un monje bizantino a comienzos del siglo XIV, el éxito no tarde en producirse. Un éxito reforzado por la imprenta.

Entre 1476 y 1477 el médico de Ulm Heinrich Steinhöwel publicó una versión bilingüe con todas las fábulas que pudo encontrar atribuidas a Esopo, a Aviano y a otros muchos, entre los que se encontraba el propio Rinuccio, y las acompañó con la biografía surgida de ambientes helenísticos y bizantinos. Posiblemente, la colección reunida por Steinhöwel ya era suficientemente destacada como para tener un éxito inmediato, pero el impresor, Johan Zainer, no se conformó con ofrecer un libro útil y bien hecho, sino que quiso enriquecerlo - como se hacía con los mejores manuscritos - con abundantes ilustraciones, y recurrió a un excelente tallista para que le preparara los tacos xilográficos; por si eso fuera poco, quiso destacar la gran novedad: por fin se sabía algo de Esopo, y para que no hubiera dudas, en la primera página imprimió un retrato muy ajustado a la descripción literaria que poseía y lo acompañó con una serie de símbolos que no dejaban dudas acerca de la vida y «pasión» del autor.

Pasión por dos razones, por los muchos sufrimientos y por la muerte que había padecido, y porque para una representación como aquélla, con el retrato de cuerpo completo del protagonista, no pudo encontrar sino las estampas habituales de las Arma Christi, el instrumental utilizado para la pasión y muerte de Jesús. Y, curiosa coincidencia, del mismo modo que la biografía procedía de ambientes griegos, así las estampas de las Arma Christi también parece que tuvieron su origen en la Iglesia Oriental. El libro recién publicado no podía pasar inadvertido a un público acostumbrado a rezar ante la imagen de un Jesucristo lleno de dolor, agonizante; ni ante un público para quien el nombre de Esopo era uno de los primeros nombres que aprendía en la escuela. El libro tampoco podía pasar inadvertido a otros impresores, y de ahí que se difundiera con rapidez por Francia, España o Inglaterra. Y, seguramente, fascinados por este Eso- 
po contrahecho $-\mathrm{y}$ no ya el maestro que aparecía en las miniaturas de antaño- y deseosos de emular al colega alemán, compartieron xilografías que de Ulm llegaron a Lyon y de Lyon a Zaragoza, para reemprender el viaje en varias ocasiones. Todo un éxito.

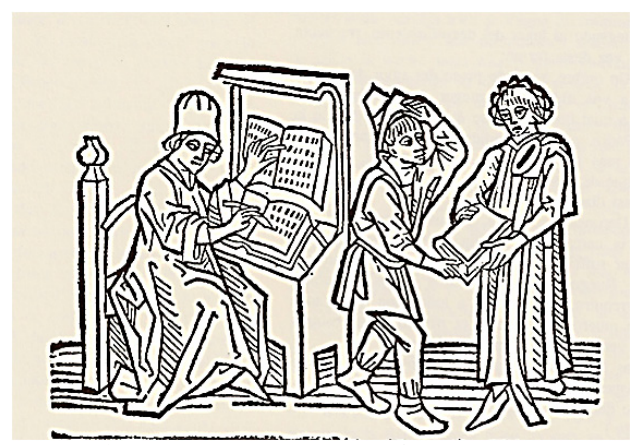

Fig. 14. Zaragoza, 1489, fol. 25v. 